\title{
Structural and Magnetic Properties of Zn-Ni Ferrite Synthesized by Precursor Method
}

\author{
Vikas J. Pissurlekar \\ Department of Chemistry, P.E.S.`s S.R.S.N College of Arts and Science, Ponda, Goa. - 403 401, India
}

\begin{abstract}
In this work nickel zinc ferrite with general formula $\mathrm{Zn}_{x} \mathrm{Ni}_{(1-x)} \mathrm{Fe}_{2} \mathrm{O}_{4}(x=0.3,0.4,0.5$ 0.6 and 0.7) were synthesized by precursor decomposition method starting from metal nitrates. X-ray analysis indicated the formation of well crystallized Zn-Ni ferrite. The change in the particle size with increasing $Z n$ content was confirmed by scanning electron microscopy which revealed that the powders prepared by precursor method resulted in nano sized particles with a particle size of 19-42 nm. The crystallite size and lattice parameter increased and Curie temperature decreased as the concentration of Zn increased. Saturation magnetization and remnant magnetization, both, continuously increase up to $x=0.5$, and then decreased for more Zn content. The influence of the grain size on saturation magnetization and of Zn on Curie temperature was investigated for the Zn-Ni ferrite samples.
\end{abstract}

Keywords: decomposition, nano sized, lattice parameter, electron microscopy, Curie temperature,

\section{Introduction}

In recent times lot of interest is generated in the study of several soft spinel ferrites in the development of nano sized particles at low temperatures by different chemical synthesis techniques, as they are commercially very important materials. Among them Ni-Zn ferrites is one of the most sought after material for use in both lower and higher frequency devices due their high resistivity, low dielectric losses, and high Curie temperature [1,2]. They have applications, such as gas sensors, as a catalyst, electromagnetic interference (EMI) suppression, multi layer chip inductor, and telecommunication devices. [3, 4]. These ferrites are also used in biomedical applications [5]. The most important properties of these ferrites are saturation magnetization, Curie temperature, resistivity, dielectric constant etc [6]. These properties are highly sensitive and are dependent on the following factors like the method of preparation, sintering temperatures and the presence of impurities. These properties can be altered as per the requirement for the specific application by controlling the preparation and sintering conditions, by changing the composition, and or by introducing required amount of additives. There are several methods of preparation of ferrites; the most common and simplest is the ceramic method involving high processing temperature. Apart from the high temperature other drawbacks of this method are evaporation of zinc due to high temperature causing chemical inhomogenity, formation of bigger particle with larger pore size material, which affects the bulk magnetic properties [7]. In order to overcome these disadvantages and to synthesize the ferrites, there are several chemical methods which are simple, environmentally friendly, economical and which gives highly pure materials like auto-combustion [8], co-precipitation [9], flash-combustion [10] hydrothermal [11], precursor [12, 13], reverse micelle [14], refluxing [15], sol-gel [16], etc. have been considered. Precursor methods are simple and economical methods for the preparation of ferrites requires lower temperature and gives highly pure products. In the present study a ligand hydrazinium oxalate was used to produce a precursor with metal nitrates in solution which were decomposed to produce nano size ferrites of nickel zinc ferrites and their structural and magnetic properties were investigated.

\section{Experimental}

Nano particles of $\mathrm{Zn}-\mathrm{Ni}$ ferrite with general formula $\mathrm{Zn}_{\mathrm{x}} \mathrm{Ni}_{(1-}$ ${ }_{x)} \mathrm{Fe}_{2} \mathrm{O}_{4}$, where $\mathrm{x}=0.3,0.4,0.5,0.6$ and 0.7 were synthesized using a precursor method. The Stoichiometric amount of analytical grade nickel nitrate $\mathrm{Ni}\left(\mathrm{NO}_{3}\right)_{2} \quad 6 \mathrm{H}_{2} \mathrm{O}$, zinc nitrate $\mathrm{Zn}\left(\mathrm{NO}_{3}\right)_{2} \quad 6 \mathrm{H}_{2} \mathrm{O}$ and ferric nitrate $\mathrm{Fe}\left(\mathrm{NO}_{3}\right)_{3} 9_{2} \mathrm{O}$, were the starting materials for this synthesis. $\mathrm{Ni}\left(\mathrm{NO}_{3}\right)_{2} \quad 6 \mathrm{H}_{2} \mathrm{O}$, $\mathrm{Zn}\left(\mathrm{NO}_{3}\right)_{2} \quad 6 \mathrm{H}_{2} \mathrm{O}$ and $\mathrm{Fe}\left(\mathrm{NO}_{3}\right)_{3} \quad 9 \mathrm{H}_{2} \mathrm{O}$ were dissolved in minimum quantity of deionized water with constant stirring, till a clear solution was formed. A calculated amount of hydrazinium oxalate ligand solution was added slowly to this solution with constant stirring to obtain a mixture. This mixture was then kept for drying on a hot plate. The mixture dried to a solid mass which auto-catalytically got decomposed into the nanoparticles solid ferrites. These powders were used for characterization and study of structural, electrical and magnetic properties.

X-ray powder diffraction (XRD), is an instrumental technique that is used to identify the crystal structure as it is reliable for material identification. As inter atomic spacing in the crystal is of the order of $10^{-8} \mathrm{~cm}$, therefore a ray with wavelength of similar order will give rise to diffraction phenomena. The structural characterization of the prepared $\mathrm{Zn}$-Ni ferrite nanoparticles was carried out using Rigaku, Xray advance Power diffractometer using $\mathrm{Cu} K \alpha$ radiation $(\lambda=$ $1 \cdot 54183 \AA$ ). The step size employed was $0 \cdot 02^{\circ}$, in the range of $20^{\circ}-80^{\circ}$.

The average crystallite size was calculated by DebyeScherer's equation using data obtained from X-ray diffractograms, for the most intense peak (311). The particle size and structural morphology studies were carried out using Scanning Electron Microscope Model JEOL 5800LV. The saturation magnetization measurements of all the samples were carried out at room temperature using Pulse Field Magnetic Hysteresis Loop Tracer, of Magneta India Model PFMHT-1. The Curie temperature measurements of the $\mathrm{Zn}$ - 


\section{International Journal of Science and Research (IJSR) \\ ISSN (Online): 2319-7064}

Index Copernicus Value (2013): 6.14 | Impact Factor (2014): 5.611

Ni ferrite samples were done by using Dual Channel Data Acquisition System supplied by Magneta India Model pfm-2.

\section{Results and Discussion:}

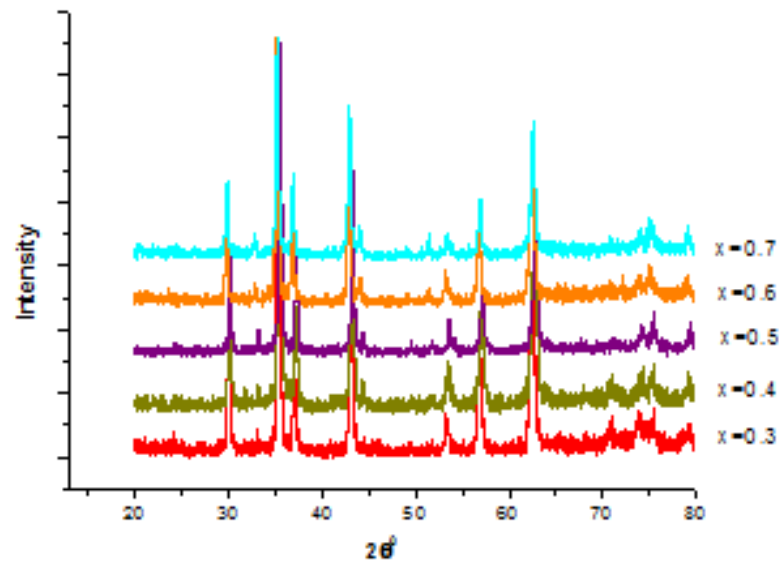

Figure 1: XRD pattern of $\mathrm{Ni}_{\mathrm{x}} \mathrm{Zn}_{(1-\mathrm{x})} \mathrm{Fe}_{2} \mathrm{O}_{4}$ samples

Formation of single phase cubic spinel structure of $\mathrm{Zn}_{\mathrm{x}} \mathrm{Ni}(1-\mathrm{x})$ $\mathrm{Fe}_{2} \mathrm{O}_{4}$ samples (with $\mathrm{X}=0.3,0.4,0.5,0.6$, and 0.7 ) synthesized by precursor decomposition method are illustrated in fig. 1. It was confirmed with help of XRD patterns obtained for all the samples.

Table 1: Variation of lattice constant of $\mathrm{Zn}_{\mathrm{x}} \mathrm{Ni}_{(1-\mathrm{x})} \mathrm{Fe}_{2} \mathrm{O}_{4}$ samples

\begin{tabular}{|c|c|}
\hline Samples & Lattice constant "a" in cm. \\
\hline $\mathrm{Zn}_{0.3} \mathrm{Ni}_{0.7} \mathrm{Fe}_{2} \mathrm{O}_{4}$ & $8.3510 \times 10^{-8}$ \\
\hline $\mathrm{Zn}_{0.4} \mathrm{Ni}_{0.6} \mathrm{Fe}_{2} \mathrm{O}_{4}$ & $8.3687 \times 10^{-8}$ \\
\hline $\mathrm{Zn}_{0.5} \mathrm{Ni}_{0.5} \mathrm{Fe}_{2} \mathrm{O}_{4}$ & $8.3963 \times 10^{-8}$ \\
\hline $\mathrm{Zn}_{0.6} \mathrm{Ni}_{0.4} \mathrm{Fe}_{2} \mathrm{O}_{4}$ & $8.4021 \times 10^{-8}$ \\
\hline $\mathrm{Zn}_{0.7} \mathrm{Ni}_{0.3} \mathrm{Fe}_{2} \mathrm{O}_{4}$ & $8.4271 \times 10^{-8}$ \\
\hline
\end{tabular}

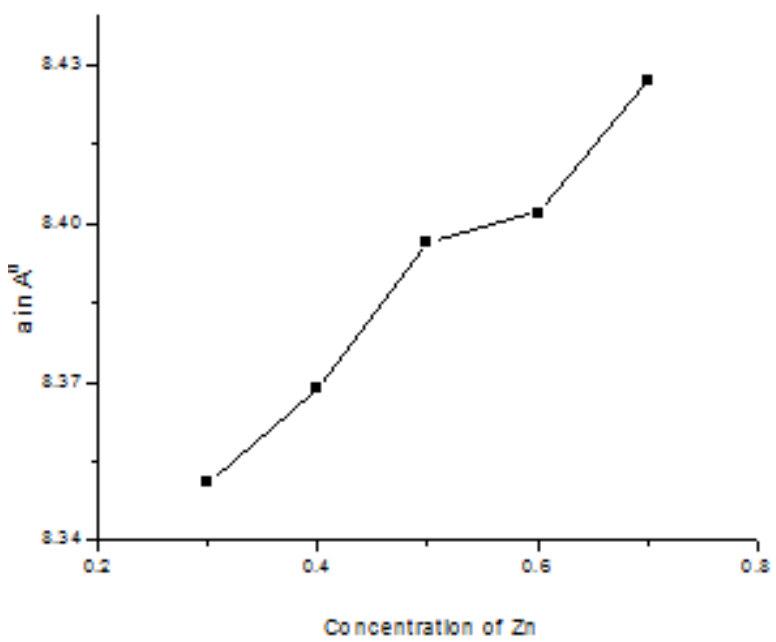

Figure 2: Variation of lattice constant

As shown in the table 1 the values of lattice constants, $\mathrm{a}^{\text {ee }}$ calculated from XRD data were found to increase with increase in $\mathrm{Zn}$ concentration. This increase is attributed to replacement of the smaller ionic radii of $\mathrm{Ni}\left(0.78 \mathrm{~A}^{\circ}\right)$ with higher $\mathrm{Zn}$ content and with larger ionic radii $\left(0.82 \mathrm{~A}^{\circ}\right)$ [17], and are in agreement with reported values.

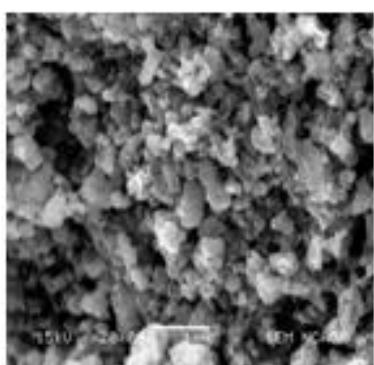

(a)

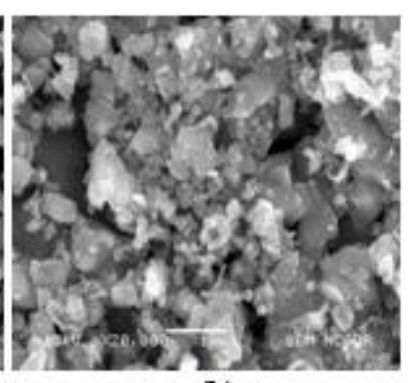

(b)
Figure 3: SEM Micrograph of $\mathrm{Ni}_{0.3} \mathrm{Zn}_{0.7} \mathrm{Fe}_{2} \mathrm{O}_{4}$ $\mathrm{Ni}_{0.6} \mathrm{Zn}_{0.4} \mathrm{Fe}_{2} \mathrm{O}_{4}$

As can be seen from the SEM micrograph Fig. 2 of $\mathrm{Zn}_{0.3} \mathrm{Ni}_{0.7} \mathrm{Fe}_{2} \mathrm{O}_{4}$ and $\mathrm{Zn}_{0.6} \mathrm{Ni}_{0.4} \mathrm{Fe}_{2} \mathrm{O}_{4}$ samples synthesized by this method that the particles are in nano range and found to increase with increasing zinc amount and this is due to higher ionic radii of $\mathrm{Zn}$ which allows the increase of particle size and also high porosity.

Table 2: Variation of particle size in $\mathrm{nm}$ of $\mathrm{Zn}_{\mathrm{x}} \mathrm{Ni}_{(1-\mathrm{x})} \mathrm{Fe}_{2} \mathrm{O}_{4}$ samples

\begin{tabular}{|c|c|}
\hline Concentration of Zinc & Particle size in $\mathrm{nm}$ \\
\hline 0.3 & 19.2 \\
\hline 0.4 & 25.6 \\
\hline 0.5 & 29.5 \\
\hline 0.6 & 37.7 \\
\hline 0.7 & 42.6 \\
\hline
\end{tabular}

The particle size of samples is calculated using the Scherer formula, indicated in table 2 is in the range from $19.2 \mathrm{~nm}$ to $42.6 \mathrm{~nm}$. This shows that the method gives nano size ferrite particles, which is also confirmed by the SEM micrograph.

Table 3: Variation of saturation magnetization of $\mathrm{Zn}_{\mathrm{x}} \mathrm{Ni}_{(1-\mathrm{x})}$ $\mathrm{Fe}_{2} \mathrm{O}_{4}$ samples

\begin{tabular}{|c|c|}
\hline Concentration & Saturation Magnetization (emu/g) \\
\hline $\mathrm{Zn}_{0.3} \mathrm{Ni}_{0.7} \mathrm{Fe}_{2} \mathrm{O}_{4}$ & 31.64 \\
\hline $\mathrm{Zn}_{0.4} \mathrm{Ni}_{0.6} \mathrm{Fe}_{2} \mathrm{O}_{4}$ & 39.28 \\
\hline $\mathrm{Zn}_{0.5} \mathrm{Ni}_{0.5} \mathrm{Fe}_{2} \mathrm{O}_{4}$ & 47.86 \\
\hline $\mathrm{Zn}_{0.6} \mathrm{Ni}_{0.4} \mathrm{Fe}_{2} \mathrm{O}_{4}$ & 41.16 \\
\hline $\mathrm{Zn}_{0.7} \mathrm{Ni}_{0.3} \mathrm{Fe}_{2} \mathrm{O}_{4}$ & 36.31 \\
\hline
\end{tabular}

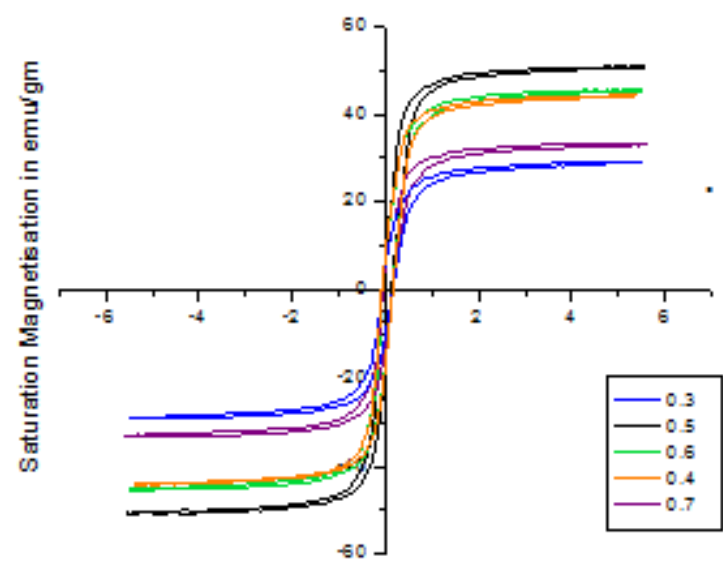

Magnetic Fleid strength in Oe

Figure 4: Variation of Saturation magnetization 


\section{International Journal of Science and Research (IJSR) ISSN (Online): 2319-7064 \\ Index Copernicus Value (2013): 6.14 | Impact Factor (2014): 5.611}

The variation of the saturation magnetization with $\mathrm{Zn}$ contents for the $\mathrm{Zn}-\mathrm{Ni}$ ferrite samples of various compositions is given in Table 3 it can be observed that the value for saturation magnetization increases with increasing $\mathrm{Zn}$ content up to $\mathrm{x}=0.5$, A marked reduction was observed for the values of $x=0.6$ and 0.7 . Based on the particle sizes, which increased with increasing $\mathrm{Zn}$ concentrations, and the theoretical magnetization foreseen for the spinel lattice, the magnetization was expected to increase. However, this increase was observed only at $\mathrm{Zn}$ concentrations of up to 0.5 . Costa [18] has attributed this behavior to the spin canting effect that occurs when B-B interactions are comparable to A-B interactions. Bercoff et al. [19] explain this phenomenon as follows: In mixed $\mathrm{Ni}-\mathrm{Zn}$ ferrites, the $\mathrm{Zn}$ ions concentrate preferentially in the A - sites and the $\mathrm{Ni}$ ions in the B- sites in the cubic spinel lattice. When the concentration of $\mathrm{Fe}^{3+}$ ions in the A- sublattice is diluted by low concentrations of diamagnetic substitutions by $\mathrm{Zn}^{2+}$ the net magnetization increases. However, magnetization decreases at higher levels of doping. The reason for this is that low $\mathrm{Zn}$ concentrations reduce the number of spins occupying the A -sublattices, causing the net magnetization to increase. As the $\mathrm{Zn}$ content increases, the exchange interactions are weakened and the Bspins are no longer held rigidly parallel to the few remaining A- spins. The decrease in the B-sublattice moment, interpreted as a spin departure from colinearity, causes the effect known as canting. This effect is also seen in other ferrites [20]

Table 4: Variation of Curie temperature of $\mathrm{Zn}_{\mathrm{x}} \mathrm{Ni}_{(1-\mathrm{x})} \mathrm{Fe}_{2} \mathrm{O}_{4}$ samples

\begin{tabular}{|c|c|}
\hline Samples & Curie temperature in ${ }^{0} \mathrm{C}$ \\
\hline $\mathrm{Zn}_{0.3} \mathrm{Ni}_{0.7} \mathrm{Fe}_{2} \mathrm{O}_{4}$ & 392 \\
\hline $\mathrm{Zn}_{0.4} \mathrm{Ni}_{0.6} \mathrm{Fe}_{2} \mathrm{O}_{4}$ & 368 \\
\hline $\mathrm{Zn}_{0.5} \mathrm{Ni}_{0.5} \mathrm{Fe}_{2} \mathrm{O}_{4}$ & 311 \\
\hline $\mathrm{Zn}_{0.6} \mathrm{Ni}_{0.4} \mathrm{Fe}_{2} \mathrm{O}_{4}$ & 247 \\
\hline $\mathrm{Zn}_{0.7} \mathrm{Ni}_{0.3} \mathrm{Fe}_{2} \mathrm{O}_{4}$ & 204 \\
\hline
\end{tabular}

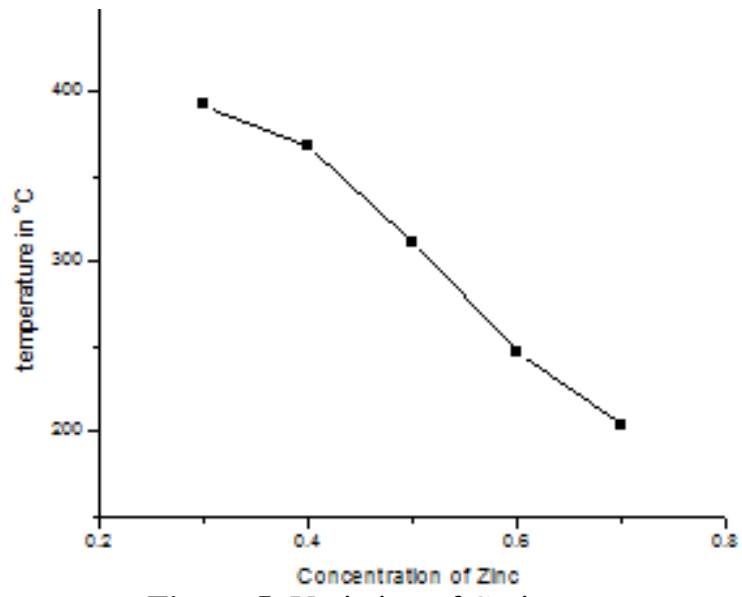

Figure 5: Variation of Curie temperature

The variation of the Curie temperature with increasing $\mathrm{Zn}$ content in $\mathrm{Zn}-\mathrm{Ni}$ ferrite samples is given in Table 4. It can be seen that, there is a systematic decrease in the value of the Curie temperature $\left(\mathrm{T}_{\mathrm{c}}\right)$ from $392^{\circ} \mathrm{C}$ for $\mathrm{Zn}_{0.3} \mathrm{Ni}_{0.7} \mathrm{Fe}_{2} \mathrm{O}_{4}$ to $204^{0} \mathrm{C}$ for $\mathrm{Zn}_{0.7} \mathrm{Ni}_{0.3} \mathrm{Fe}_{2} \mathrm{O}_{4}$ as the zinc amount increases in these ferrites. This is due to the substitution of non-magnetic $\mathrm{Zn}^{2+}$ ions for the magnetic $\mathrm{Ni}^{2+}$ ions in the samples. The decrease in Curie temperature with zinc content is attributed to the decrease of $\mathrm{A}-\mathrm{B}$ interaction. As the content of zinc is increased, the relative number of $\mathrm{Fe}^{3+}$ ions on A-site decreases, which causes a reduction in the $\mathrm{A}-\mathrm{B}$ interaction $[21,22]$.

\section{Conclusion}

$\mathrm{Zn}$ - Ni ferrite with general formula $\mathrm{Zn}_{\mathrm{x}} \mathrm{Ni}$ (1-x) $\mathrm{Fe}_{2} \mathrm{O}_{4}$ where $\mathrm{X}=0.3,0.4,0.5,0.6$, and 0.7 were prepared by precursor decomposition method. The single phase formation was confirmed by XRD. SEM analysis indicated a high level of powder agglomeration. The size of the crystallites increases when more $\mathrm{Ni}$ ions were replaced by $\mathrm{Zn}$ ions. Magnetic measurements showed that magnetization was rising with increasing of $\mathrm{Zn}$ content up to $\mathrm{x}=0.5$ and followed by a decrease for higher $\mathrm{Zn}$ concentration. It was observed that, there is a systematic decrease in the value of the Curie temperature $\left(\mathrm{T}_{\mathrm{c}}\right)$, as the zinc amount is increased in these ferrites. This is due to the substitution of non-magnetic $\mathrm{Zn}^{2+}$ ions for the magnetic $\mathrm{Ni}^{2+}$ ions in the samples.

\section{Acknowledgements}

The author is grateful to the University Grants Commission (UGC) New Delhi India for providing the financial grant under minor research project.

\section{References}

[1] C. Venkataraju, G. Sathishkumar, K. Sivakumar, "Effect of cation distribution on the structural and magnetic properties of nickel substituted nano sized $\mathrm{Mn}-\mathrm{Zn}$ ferrites prepared by co-precipitation method", J. Magn. Magn. Mater., 322 (2010) 230-233.

[2] H. Igarashi, K. Ohazaki, "Effects of porosity and grain size on the magnetic properties of $\mathrm{Ni}-\mathrm{Zn}$ ferrite",J. American Ceramic Society, 60 (1997) 51-54.

[3] M. Siva Ram Prasad, B. B. V. S. V. Prasad, B. Rajesh, K. H. Rao, K. V. Ramesh, J. Magn. Magn. Mater. 323 (2011) 2115-2121.

[4] S. Maensiri, C. Masingboon, B. Boonchom, S. Seraphin, "A simple route to synthesize nickel ferrite $\left(\mathrm{NiFe}_{2} \mathrm{O}_{4}\right)$ nanoparticles using egg white", Scr. Mater. 56 (2007) 797-800

[5] B.K. Sunkara, R.D.K. Misra, Acta Biomater. 4 (2008) 273

[6] P. P. Sarangi, S. R. Vadera, M. K. Patra, N. N. Ghosh, Powder Technol 203(2010) 348-353.

[7] A. Verma, T. C. Goel, R. G. Mendiratta, R. K. Gupta, "High resistivity $\mathrm{Ni}-\mathrm{Zn}$ ferrites by citrate precursor method", J. Magn. Magn. Mater., 192 (1999) 271-276.

[8] A. S. Džunuzović, N. I. Ilić, M. M. Vijatović Petrović, J. D. Bobić, B. Stojadinović, Z. Dohčević-Mitrović, B. D. Stojanović, J. Magn. Magn. Mater. 374 (2015) 245-251

[9] J. Yang, W. Tsuo, F. Yen, Preparation of ultra fine nickel ferrite powders using mixed $\mathrm{Ni}$ and Fe tartarates, J. Solid State Chem., 145(1999)50-57.

[10] R. V. Mangalaraja, S. Thomas Lee, S. Ananthakumar, P. Manohar, P. Camurri, "Effect of composition on initial permeability of Ni1_xZnxFe2O4 prepared by flash

\section{Volume 4 Issue 12, December 2015}




\section{International Journal of Science and Research (IJSR) \\ ISSN (Online): 2319-7064}

Index Copernicus Value (2013): 6.14 | Impact Factor (2014): 5.611

combustion technique" Materials Science and Engineering A 476 (2008) 234-239.

[11]B. Baruwati, R. K. Rana, S. V. Manorama, "Further insights in the conductivity behavior of nano crystalline $\mathrm{NiFe}_{2} \mathrm{O}_{4}$ ", J. Appl.Phys.101 (2007) 014302-014308.

[12] S. Prasad, N. Gajbhiye, "Magnetic studies of nano sized nickel ferrite particles synthesized by the citrate precursor technique", J. Alloys Compd. 265 (1998) 8792.

[13]M. M. Hessien, "Synthesis and characterization of lithium ferrite by oxalate precursor route", J. Magn. Magn. Mater. 320 (2004)2800-2807.

[14] Thakur Sangeeta, Katyal S. C. Singh M., "Structural and magnetic properties of nano nickel-zinc ferrite synthesized by reverse micelle technique", J. Magn. Magn. Mater. 321 (2009) 1-7.

[15]X. D. Li, W. S. Yang, F. Li, D.G. Evans, X. Duan, "Stoichiometric synthesis of pure $\mathrm{NiFe}_{2} \mathrm{O}_{4}$ spinel from layered double hydroxide precursors for use as the anode material in lithium-ion batteries", J. Phys. Chem. Solids 67 (2006)1286-1290.

[16]Ali Ghasemin, Mohammad Mousavinia Ceramics International 40 (2014) 2825-2834.

[17] H. Rahmouni, A. Benali, B. Cherif, E. Dhahri, M. Boukhobza, K. Khirouni, M. Sajieddine, "Structural and electrical properties of $\mathrm{Zn}_{1-\mathrm{x}} \mathrm{Ni}_{\mathrm{x}} \mathrm{Fe}_{2} \mathrm{O}_{4}$ ferrite, Physica B 466-467 (2015) 31-37.

[18] A.C.F.M. Costa. "Synthesis for Combustion Reaction, Sinterizaction and Ferrites Characterization $\mathrm{Ni}-\mathrm{Zn}$ Thesis" (Doctorate in Sciences and Engineering of Materials) Department of Engineering of Materials, Federal University of Sao Carlos, Sao Carlos, 2002.

[19] P.G. Bercoff, et al., J. Magn. Magn. Mater. 213 (2000) 56.

[20]A. A. Sattar, et al., Phys. State Solid 171 (1999) 563.

[21] A. K. M. Akther Hossain, S. T. Mahmud, M. Seki, T. Kawai, H. Tabata, "Structural, electrical transport, and magnetic properties of $\mathrm{Ni}_{1-\mathrm{x}} \mathrm{Zn}_{\mathrm{x}} \mathrm{Fe}_{2} \mathrm{O}_{4}$ ", J. Magn.Magn. Mater. 312 (2007) 210-219.

[22] T. J. Shinde, A. B. Gadkari, P. N. Vasambekar "Magnetic properties and cation distribution study of nanocrystalline Ni-Zn ferrites", J.Magn. Magn. Mater. 333 (2013) 152-155 